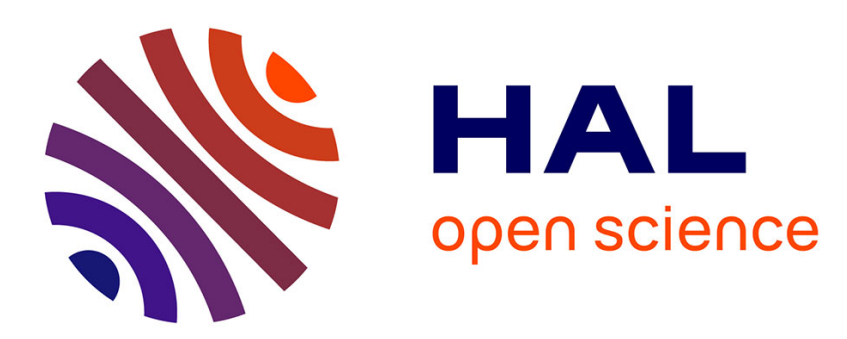

\title{
The distribution of iodine in the Croatian marine lake, Mir - The missing iodate
}

\author{
Vesna Zic, Victor W. Truesdale, Cédric Garnier, Neven Cukrov
}

\section{To cite this version:}

Vesna Zic, Victor W. Truesdale, Cédric Garnier, Neven Cukrov. The distribution of iodine in the Croatian marine lake, Mir - The missing iodate. Estuarine, Coastal and Shelf Science, 2012, 115, pp.377-387. 10.1016/j.ecss.2012.07.026 . hal-01096854

\section{HAL Id: hal-01096854 \\ https://hal-univ-tln.archives-ouvertes.fr/hal-01096854}

Submitted on 5 Jan 2015

HAL is a multi-disciplinary open access archive for the deposit and dissemination of scientific research documents, whether they are published or not. The documents may come from teaching and research institutions in France or abroad, or from public or private research centers.
L'archive ouverte pluridisciplinaire HAL, est destinée au dépôt et à la diffusion de documents scientifiques de niveau recherche, publiés ou non, émanant des établissements d'enseignement et de recherche français ou étrangers, des laboratoires publics ou privés. 
Provided for non-commercial research and education use. Not for reproduction, distribution or commercial use.

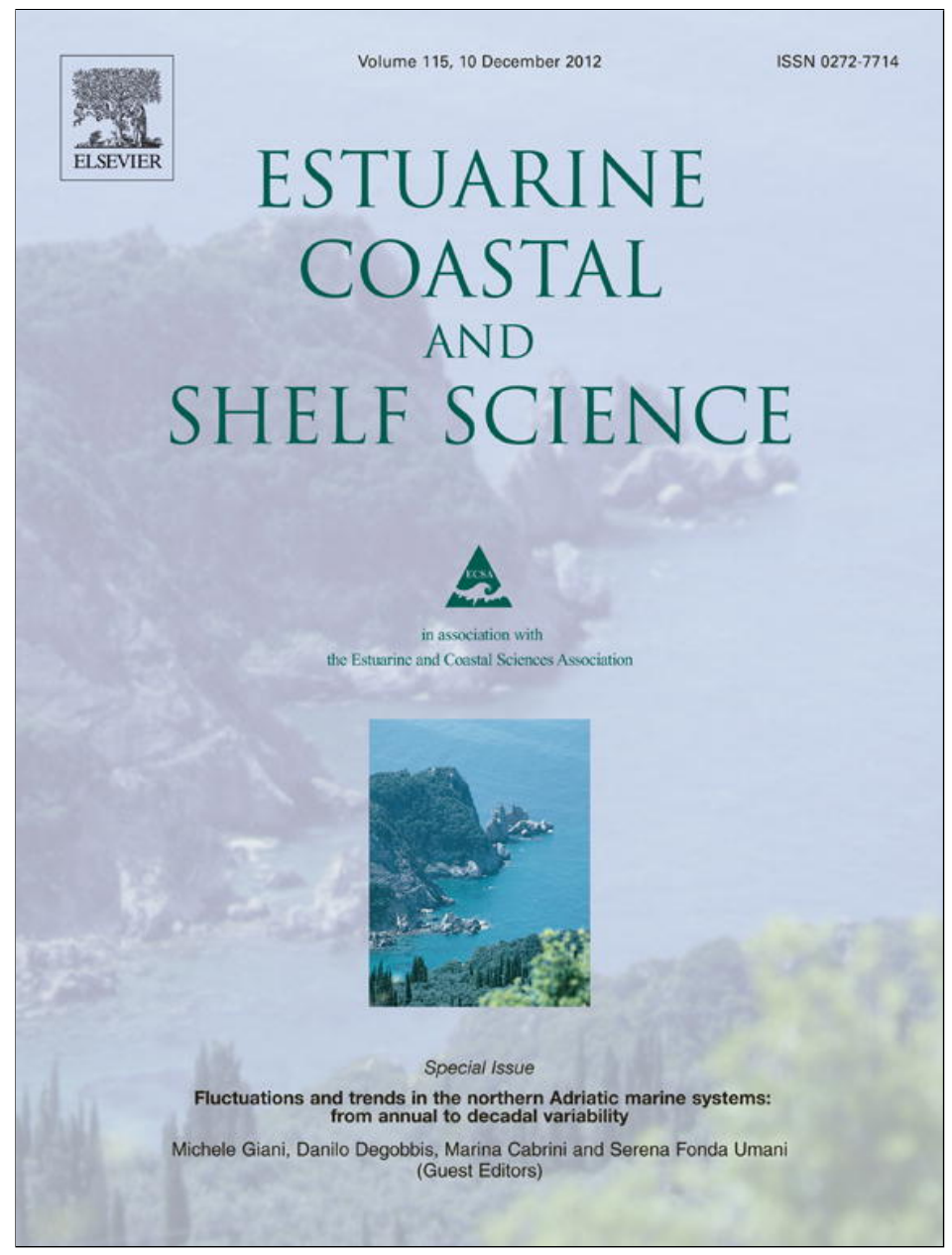

This article appeared in a journal published by Elsevier. The attached copy is furnished to the author for internal non-commercial research and education use, including for instruction at the authors institution and sharing with colleagues.

Other uses, including reproduction and distribution, or selling or licensing copies, or posting to personal, institutional or third party websites are prohibited.

In most cases authors are permitted to post their version of the article (e.g. in Word or Tex form) to their personal website or institutional repository. Authors requiring further information regarding Elsevier's archiving and manuscript policies are encouraged to visit:

http://www.elsevier.com/copyright 


\title{
The distribution of iodine in the Croatian marine lake, Mir - The missing iodate
}

\author{
Vesna Žic ${ }^{\mathrm{a}, \mathrm{b}, *}$, Victor W. Truesdale ${ }^{\mathrm{c}}$, Cédric Garnier ${ }^{\mathrm{d}}$, Neven Cukrov ${ }^{\mathrm{a}}$ \\ ${ }^{a}$ Division for Marine and Environmental Research, Ruđer Bošković Institute, Bijenička 54, 10001 Zagreb, Croatia \\ ${ }^{\mathrm{b}}$ Central Water Management Laboratory, Hrvatske vode, Uvala Škar b.b., p.p. 40, 22001 Šibenik, Croatia

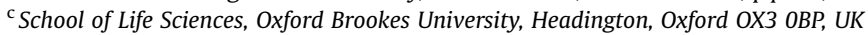 \\ ${ }^{d}$ Laboratoire PROTEE, Université du Sud Toulon-Var, BP 20132, 83957 La Garde, France
}

\section{A R T I C L E I N F O}

\section{Article history:}

Received 16 January 2012

Accepted 27 July 2012

Available online 4 August 2012

\section{Keywords:}

iodate

iodide

organic iodine

nutrients

marine lakes

Croatia

Dugi Otok

Lake Mir

\begin{abstract}
A B S T R A C T
The marine chemistry of iodine has been studied in the marine lake, Mir, regarded as a natural reactor situated in the karstificated carbonate rocks of the Croatian Adriatic coast. The investigation covered the major variables: salinity, temperature, dissolved oxygen, $\mathrm{pH}$ and alkalinity, some nutrients, organic carbon, and iodide, iodate and organic-I. Lake Mir was found to be meso-trophic, with dynamic nutrient cycling of a magnitude usually associated with the temperate zone but within a Mediterranean clime. An essentially U-shaped pattern exists in the plot of nutrient concentration versus time for the June-November period studied. Together, the major variables and the nutrient chemistry confirm that Lake Mir is essentially isolated from the nearby $(90 \mathrm{~m})$ Adriatic seawater, and this also may explain the meso-trophic nature of the lake, with dry and wet deposition as the source of the extra nutrient. It is of note that iodate was essentially absent from Mir during the sampling period. This appears to be consistent with iodine's behaviour in the oceans in general, where iodate is reduced generally as a result of the presence of the biota. The chemistry of iodine in Lake Mir is consequently dominated by changes in iodide and organic-I concentrations, with the latter at higher concentrations than those found in seawater. Even so, the total iodine concentration in Mir is only about one-quarter of that in the adjacent Adriatic seawater, and again it is argued that this is probably a function of Lake Mir's isolation.
\end{abstract}

(c) 2012 Elsevier Ltd. All rights reserved.

\section{Introduction}

Dissolved iodine is generally present in seawater as iodate, iodide and organically bound iodine, at a total concentration of about $0.45 \mu \mathrm{mol} \mathrm{l}^{-1}$ (Sugawara and Terada, 1957; Truesdale, 1975, 1994a; Elderfield and Truesdale, 1980; Nakayama et al., 1989; Wong, 1991; McTaggart et al., 1994; Campos et al., 1996). In the open, surface oxic oceans there is a zonal change from high proportions of iodate at the poles (Campos et al., 1999; Waite et al., 2006; Chance et al., 2010), to high proportions of iodide in the equatorial regions (Sugawara and Terada, 1957; Tsunogai and Henmi, 1971; Truesdale et al., 2000). A similar trend exists across the temperate continental shelf (Truesdale, 1978, 1994b; Wong and Zhang, 1992a; Wong, 1995; Truesdale and Jones, 2000; Truesdale and Upstill-Goddard, 2003). The zonal trend is consistent with the general oceanic circulation model (Broecker et al., 1982) where surface water sinks at high latitudes during winter, travels

\footnotetext{
* Corresponding author. Present address: Central Water Management Laboratory, Hrvatske vode, Uvala Škar b.b., 22001 Šibenik, Croatia.

E-mail addresses: vesna.zic@si.t-com.hr (V. Žic), vtruesdale@brookes.ac.uk (V.W. Truesdale), cgarnier@univ-tln.fr (C. Garnier), ncukrov@irb.hr (N. Cukrov).
}

southwards down the Atlantic, to join similar convective processing occurring around the Antarctic Continent. Eventually this water is released back to the surface flow in the Indian and Pacific Oceans. Accordingly, deep water in all the major ocean basins is high in iodate and low in iodide. Meanwhile, in anoxic systems, iodide is the predicted form of iodine (Wong and Brewer, 1977; Wong et al., 1985; Truesdale et al., 2001a; Waite et al., 2006).

Dissolved organic-I is mostly associated with inshore waters, since in open oceans it is a minor component and it represents only few percent of the total dissolved iodine pool (Truesdale, 1975). In near-shore environments, particularly estuarine waters, organic-I can sometimes exceed the sum of the inorganic fractions (Luther et al., 1991; Cook et al., 2000; Wong and Cheng, 2001a; Wong and Zhang, 2003; Schwehr and Santschi, 2003; Schwehr et al., 2005). The contribution of organic-I to total iodine generally increases with decreasing salinity, and is found to be associated with either higher productivity of these waters or greater input of terrestrial organic matter. The same pattern has been also confirmed in subterranean anchialine waters (Žic et al., 2011), which could well be regarded as subterranean (groundwater) estuaries (Moore, 1999; Humphreys, 2009). There, organic-I is derived from the porous carbonate bedrock. In humic-rich 
(Gilfedder et al., 2009) and oligotrophic (Gilfedder et al., 2010) limnic environments organic-I also predominates.

Iodine is generally thought of as a biophilic element although in seawater it is bio-intermediate. Thus, iodine is known to be absorbed by some macro-algae, e.g., Laminaria digitata (Shaw, 1959), concentrating at the extremely high $3 \cdot 10^{4}$ times relative to its concentration in seawater. In microscopic algae the concentrations are much lower. However, a fairly abundant literature giving both the distribution of iodine and its interaction with these still leaves the precise mode of its oceanic cycling in doubt. In summary, uptake is small in comparison with reduction of dissolved iodate, I ( +5$)$, to iodide, I ( -1$)$ (Sugawara and Terada, 1967; Tsunogai and Sase, 1969; Wong et al., 2002; Waite and Truesdale, 2003), and while iodate and iodide have been purported to be inter-converted by various species of these organisms, the culturing work (Sugawara and Terada, 1967; Tsunogai and Sase, 1969; Wong et al., 2002; Waite and Truesdale, 2003; Chance et al., 2007) does not agree with the field observations. To some, other microscopic organisms, e.g., non-photosynthetic bacteria, seem more likely to be involved, simply because the annual phytoplankton bloom in the temperate regions has not been linked definitively to iodate reduction (Truesdale, 1978, 1994a,b; Truesdale and Jones, 2000; Truesdale and Bailey, 2000, 2002; Truesdale et al., 2003a,b). Truesdale (1994a) re-assessed the evidence which originally suggested that algae were the likely agents of reduction (Elderfield and Truesdale, 1980).

The present study arose out of an iodine survey conducted on the marine lake, Mir in 2010. The lake was chosen as Žic and Branica (2006) and Žic et al. (2010) had shown that another, physically comparable anchialine system (Greek: ayxi-ádóo - near the sea; Holthuis, 1973) in Croatia behaves as an isolated "reactor" in which various biogeochemical processes operate differently to those in open seas. Lake Mir is further of interest because, in spite its short distance from the surrounding Adriatic $(\approx 90 \mathrm{~m}$ ), it displays up to four times a lower concentration of total iodine than does the nearby open seawater, with barely discernible iodate concentrations $\left(\approx 0.02 \mu \mathrm{mol} \mathrm{l}^{-1}\right)$. These preliminary results provoked the more intensive sampling of the lake over the summer and autumn 2011.

\section{Study area}

Lake Mir is a marine lake located at the eastern coast of the Adriatic Sea $\left(43^{\circ} 53^{\prime} 12^{\prime \prime} N, 15^{\circ} 10^{\prime} \mathrm{E}\right)$, at the south-eastern part of the island Dugi Otok in the Nature Park Telašćica (Fig. 1), formed by marine submersion of karst uvala (compound sinkholes). The lake is elongated, $\approx(0.9-0.3) \mathrm{km}$, with a surface area of $\approx 0.23 \mathrm{~km}^{2}$ and a maximum depth of ca. $7 \mathrm{~m}$. There is no obvious surface connection to the sea nor any known extensive sub-surface, tunnel-like, connection, so that seawater replenishment is restricted. Despite the fissures and cracks that are to be found in the rock at its northern and south-western part, communication with the surrounding Adriatic Sea is minimal since the lake's tidal range is only about $1 \mathrm{~cm}$ (Džaja, 2003), compared to the mean daily tidal range of $25 \mathrm{~cm}$ in the adjacent sea (Croatian Hydrographic Institute). The lake's low tidal range (less than $2 \mathrm{~cm}$ ) was also confirmed during spring of 2012 with Sensus Ultra (ReefNet) data loggers ( $\mathrm{N}$. Cukrov, pers. comm.). The shores of the lake are rocky and the lake bottom in shallow areas (up to around $2 \mathrm{~m}$ ) is rocky and/or sandy with gravels. At greater depths it becomes muddier, covered with clay or fine grey silt. The deepest regions are covered with pellet mud, and during phytoplankton blooms these sediments could be overlaid with formations of mucilaginous aggregates.
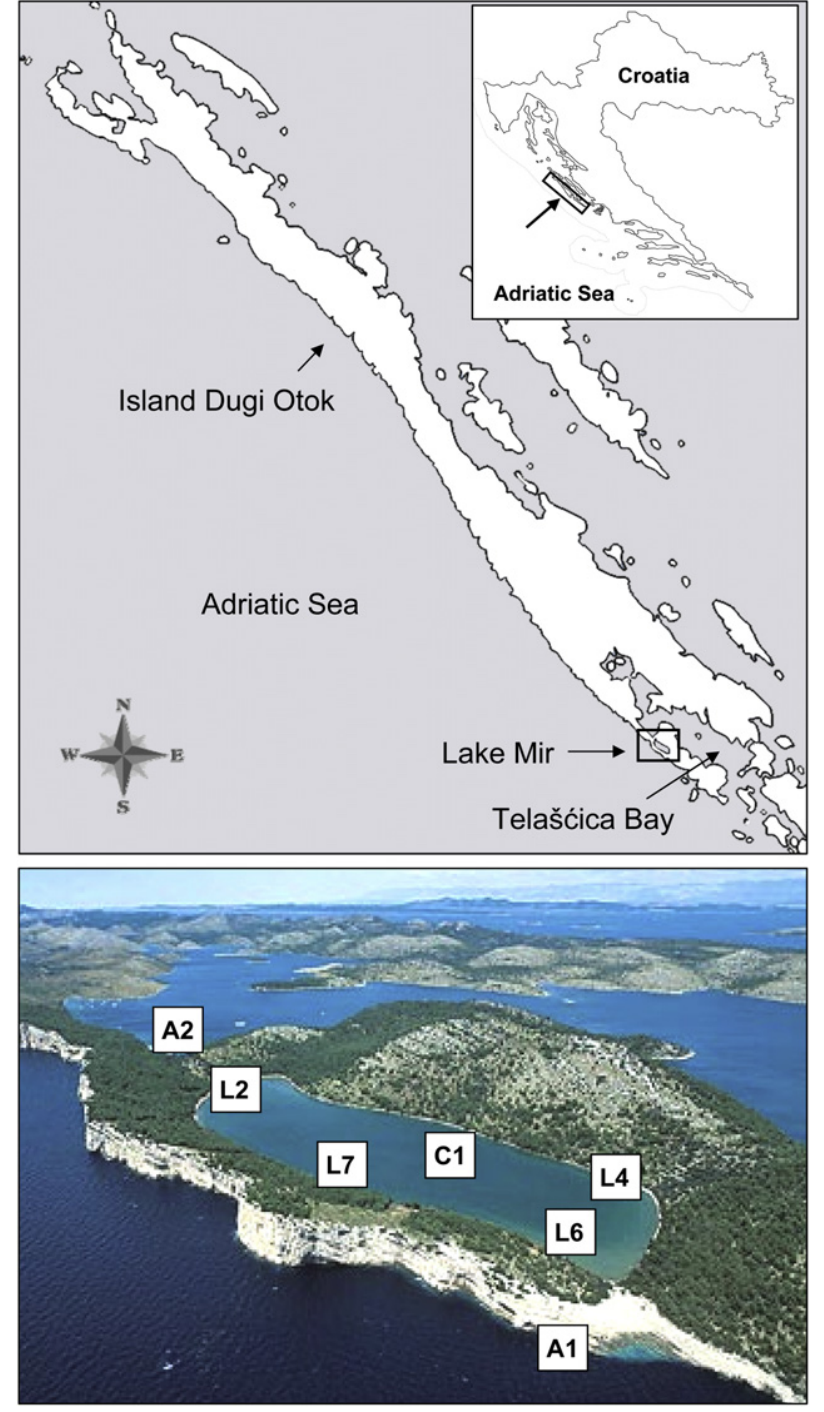

Fig. 1. The geography of the sampling locations. Lake Mir in relation to the Croatian coast (upper figure). The sampling positions on Lake Mir, and the two marine on the Adriatic coast (A1 and A2) (lower figure).

\section{Sampling and analysis of waters}

\subsection{Sampling}

Surface water samples from Lake Mir and the Adriatic Sea were collected in March 2010 (Fig. 1, Table 1) and between June and October 2011 at Stations L7 and A1 (Fig. 1), approximately twice per month. Depth profiles at the central lake station C1 (Fig. 1) were taken in June and September 2010 and July 2011 by a scuba diver progressively

Table 1

Salinity, alkalinity, iodate, iodide, total inorganic iodine and total iodine concentrations in surface samples at two marine (A1, A2) and four Lake Mir stations (L2, L4, L6, L7) in March 2010.

\begin{tabular}{lllllll}
\hline Station & $S$ & $\begin{array}{l}A \\
\left(\mathrm{mmol} \mathrm{l}^{-1}\right)\end{array}$ & $\begin{array}{l}c\left(\mathrm{IO}_{3}{ }^{-}\right) \\
\left(\mu \mathrm{mol} \mathrm{l}^{-1}\right)\end{array}$ & $\begin{array}{l}c\left(\mathrm{I}^{-}\right) \\
\left(\mu \mathrm{mol} \mathrm{l}^{-1}\right)\end{array}$ & $\begin{array}{l}c(\mathrm{TII}) \\
\left(\mu \mathrm{mol} \mathrm{l}^{-1}\right)\end{array}$ & $\begin{array}{l}c(\mathrm{TI}) \\
\left(\mu \mathrm{mol} \mathrm{l}^{-1}\right)\end{array}$ \\
\hline $\mathrm{A} 1$ & 38.5 & 2.71 & 0.340 & 0.080 & 0.420 & 0.437 \\
$\mathrm{~A} 2$ & 38.0 & 2.86 & 0.330 & 0.085 & 0.415 & 0.417 \\
$\mathrm{~L} 2$ & 37.0 & 2.95 & 0.024 & 0.052 & 0.076 & 0.102 \\
$\mathrm{~L} 4$ & 37.0 & 3.03 & 0.027 & 0.050 & 0.077 & 0.104 \\
$\mathrm{~L} 6$ & 37.0 & 2.97 & 0.022 & 0.050 & 0.072 & 0.095 \\
$\mathrm{~L} 7$ & 37.0 & 2.98 & 0.020 & 0.051 & 0.071 & 0.093 \\
\hline
\end{tabular}


working deeper, so as to minimise disturbance. In September 2010 dense foam accumulated down-wind on the lake's surface, and the diver found mucilaginous aggregates at the bottom of the lake.

\subsection{The major variables}

Salinity, temperature and dissolved oxygen concentration depth profiles were determined in situ by a Hach Lange HQ40D Multimeter. Salinity was calibrated by potassium chloride solution supplied by the manufacturer, while the oxygen meter used an automatic internal calibration, and was occasionally checked for a $100 \%$ of saturation. Immediately after collection the $\mathrm{pH}$ of samples was measured with an MP120-B (Mettler-Toledo AG) pH-Meter with an In Lab 427 electrode. The $\mathrm{pH}$ electrode was calibrated with standard $\mathrm{pH} 4$ and 7 buffer solutions, and since no correction was made for ionic strength, the $\mathrm{pH}$ measurements are operational.

The salinity of surface samples was calculated from chlorinity, itself determined by a Mohr's titration (Millero, 2006), with a precision of $\pm 0.5 \%$. Temperature was measured in situ with a mercury in glass thermometer, while $\mathrm{pH}$ was determined by $\mathrm{pH}$ $300 \mathrm{pH}-$ Meter (Hanna Instruments). Alkalinity was determined according to ISO 9963/1:1995(E), by titration with $0.100 \mathrm{~mol} \mathrm{l}^{-1}$ hydrochloric acid solution using Bromocresol Green-Methyl Red indicator. The relative standard deviation (Coefficient of variation) on replicate samples was less than $\pm 1 \%$.

\subsection{The iodine speciation}

The concentrations of iodate, iodide and total iodine in unfiltered samples were measured by voltammetry, using a PAR 384B Electrochemical Analyser in conjunction with PAR 303A static mercury drop electrode (SMDE), with an $\mathrm{Ag} / \mathrm{AgCl}$ (sat. $\mathrm{NaCl}$ ) reference electrode and a platinum wire as a counter electrode. Iodate and iodide were determined directly by differential pulse voltammetry (Herring and Liss, 1974) and cathodic stripping square wave voltammetry (Luther et al., 1988), respectively. Total iodine (TI) was determined indirectly as iodate after oxidation of reduced iodine species by UV-irradiation ( $24 \mathrm{~h}, 150-\mathrm{W}$ mercury lamp; Hanau, Germany) in the presence of hydrogen peroxide. This was followed by treatment with hypochlorite to destroy any trace of peroxide as well as to re-oxidise iodine species of lower oxidation state than iodate that might have formed during irradiation (Truesdale, 1975; Butler and Smith, 1980; Stipaničev and Branica, 1996; Wong and Cheng, 1998). To facilitate the removal of dissolved oxygen, as well as to destroy the excess of hypochlorite, sodium sulfite was also added to the samples (Wong and Zhang, 1992b). Peak currents were determined from the baselinecorrected voltammograms, with either the baseline being constructed using a spline function or by second-derivative mode implemented in a home-written software package, ECDSOFT (Omanović and Branica, 1998; Pižeta et al., 1999; Omanović, 2006).

Calibration was by the standard addition method and linear regression analysis was used to calculate the concentration in the original sample. This offered a high level of analytical quality control as any deterioration of the methods was detectable early, either in poor replication of the calibrations or poor overall reproducibility. Detection limits in iodate and iodide analyses were around $0.015 \mu \mathrm{mol}^{-1}$ and $0.001 \mu \mathrm{moll}^{-1}$, respectively. The overall precision was evaluated from a larger set of duplicate measurements, as described by Currie and Svehla (1994), and expressed as a relative standard deviation, it was typically within $\pm 2 \%$ for iodate, $\pm 4 \%$ for iodide and $\pm 5 \%$ for total iodine analyses. The concentration of organic iodine was calculated as the difference between total iodine (TI) and total inorganic iodine (TII; iodate + iodide) concentration, so that precision was about $\pm 10 \%$. Iodine samples were stored in the dark at $4{ }^{\circ} \mathrm{C}$ for no more than a week before analysis.

\subsection{Nutrient analysis}

The concentrations of nutrients were measured on Perkin Elmer Lambda $25 \mathrm{UV} / \mathrm{Vis}$ spectrometer. Due to the higher concentration of organic matter in lake samples, the spectral curves were corrected for the background absorbance either by omission of a key reagent specified by the method or by application of second-derivative spectroscopy.

Nitrate + nitrite, nitrite and ammonium were measured according to Zhang and Fischer (2006), Griess-Ilosvay method (Strickland and Parsons, 1968) and Bower and Holm-Hansen (1980), with method detection limits of about $0.5 \mu \mathrm{mol} \mathrm{l}^{-1}$, $0.03 \mu \mathrm{mol} \mathrm{l}^{-1}$ and $0.4 \mu \mathrm{mol} \mathrm{I}^{-1}$, respectively, and the overall precision $\pm 10 \%$.

Orthophosphate and total phosphorus concentrations were analysed according to ISO 6878:1998(E). The method is based on formation of phosphomolybdate complex, which is subsequently reduced with ascorbic acid to form a strongly coloured blue molybdenum complex, the absorbance of which is measured spectrometrically at about $880 \mathrm{~nm}$. For total phosphorus determination, prior to orthophosphate ions analyses, samples were digested with sulfuric acid and nitric acid, the reagents that are more effective in the presence of large quantities of organic matter than peroxodisulfate oxidation. Detection limits in orthophosphate and total phosphorus analyses were $0.04 \mu \mathrm{mol} \mathrm{I}^{-1}$ and $0.15 \mu \mathrm{mol}^{-1}$, respectively, while precision was typically better than $\pm 10 \%$. Samples were analysed within $48 \mathrm{~h}$.

\subsection{Dissolved and particulate organic carbon}

To determine the total and dissolved organic carbon content, an aliquot was filtered on 25-mm glass filters (GFF, Whatman) using an all-glass filtering system (Wheaton) under vacuum. All the glass equipment (filter, tubes, filtering system) was calcined at $450{ }^{\circ} \mathrm{C}$ for $4 \mathrm{~h}$ prior to use. The resulting dissolved fraction was stored in a 24-ml glass tube equipped with a teflon/silicone septum (Wheaton), and poisoned with $50 \mu \mathrm{l}$ of $1 \mathrm{~mol} \mathrm{l}^{-1} \mathrm{NaN}_{3}$ (Aldrich), and stored in the dark at $4{ }^{\circ} \mathrm{C}$ until analysis. Filters were dried to constant weight at $60^{\circ} \mathrm{C}$, and then exposed to $\mathrm{HCl}$ fumes for $4 \mathrm{~h}$ to remove all the inorganic carbon (Lorrain et al., 2003). The dissolved organic carbon (DOC) concentrations were determined using a Shimadzu TOC-VCSH analyser, using the high-temperature $\left(680{ }^{\circ} \mathrm{C}\right)$ catalytic oxidation method with IR detection of $\mathrm{CO}_{2}$ (Benner and Strom, 1993), calibrated using potassium hydrogen phthalate (Fisher Scientific, Analytical Reagent grade) (Louis et al., 2009). The particulate organic carbon (POC) concentration on the filters was determined using the same equipment, via the Shimadzu SSM-5000 module which uses catalytic oxidation at $950{ }^{\circ} \mathrm{C}$, and is calibrated using glucose (Fisher Scientific, Analytical Reagent grade). The sum of the DOC and the POC yielded the total organic carbon (TOC) content to an accuracy of $10 \%$. Precision was typically better than $\pm 5 \%$.

\section{Results}

\subsection{The preliminary survey}

The preliminary survey in March 2010 showed that spatially, the major constituents of Mir Lake surface water were fairly constant, and close to that of Adriatic water (Table 1). Thus, salinity and alkalinity in shore samples from positions L2, L4, L6 and L7 (Fig. 1) were $37.0( \pm 0.3)$ and $2.98( \pm 0.03) \mathrm{mmol} \mathrm{l}^{-1}$, respectively, which 
corresponds well with values of $38.0( \pm 0.3)$ and 2.79 $( \pm 0.11) \mathrm{mmol} \mathrm{l}^{-1}$, respectively, in the Adriatic seawater at A1 and A2. Meanwhile, the concentration of TII of $0.074( \pm 0.003) \mu \mathrm{mol} \mathrm{l}^{-1}$ in lake water was about $20 \%$ of that in seawater. This difference in concentration was greater for iodate than for iodide as the iodate concentration was only $8 \%$ of the seawater value, while that of iodide was $62 \%$ of the seawater value. The organic-I concentration in the lake (TI-TII) was slightly higher in the lake than in the sea.

\subsection{Depth profiles at station $\mathrm{C} 1$}

\subsubsection{Major constituents}

In June and September 2010 the depth profiles for the major constituents (salinity, temperature, dissolved oxygen, alkalinity, and $\mathrm{pH}$ ) confirmed the consensus (e.g., Carić et al., 2010) that Lake Mir is well mixed (Fig. 2). In July 2011 this also appears to have been the case up to around $5 \mathrm{~m}$, but the deeper water may be stratified. Given the lower temperature and salinity of the bottom water this appears to have been caused by a lack of mixing during the summer, with warming and evaporation of near surface water. This corresponds with a period of stable meteorology, lacking rain and strong winds. Alkalinity and $\mathrm{pH}$ measurements, where made, comply with this interpretation. The depth profile of dissolved oxygen in July 2011 indicates that most of the water column was oxic. Hypoxic conditions were representative only in the deepest layer.

\subsubsection{Nutrients}

Although the differences in distribution are only minor, over the period from June to September 2010 nitrate and nitrite concentrations decreased, and that of ammonium increased (Fig. 2). This appears to agree with a system in which nitrate is taken up in the spring bloom, but ammonium is the form to which nitrogen is predominantly regenerated, particularly later in the year. The profiles in July 2011 additionally confirm this seasonal pattern in the upper half of the water column. Meanwhile, and in accordance with the vertical profiles for the major constituents, regeneration of nutrients from settling algae and a possible diffusion of ammonium out of the lake sediment predominates in the bottom waters.

\subsubsection{Organic carbon and suspended solids in July 2011}

The profiles of particulate and dissolved-organic carbon (Fig. 2), as well as of suspended solids were relatively uniform with depth, with the mean values $( \pm$ s.d.) of $0.13( \pm 0.01), 0.31$ $( \pm 0.01) \mathrm{mmol} \mathrm{l}^{-1}$, and $9.3( \pm 0.8) \mathrm{mg} \mathrm{l}^{-1}$, respectively. Meanwhile, the seawater sample from marine station $A 1$ on the same day had POC and DOC concentrations of only $0.01 \mathrm{mmol} \mathrm{l}^{-1}$ and $0.09 \mathrm{mmol} \mathrm{l}^{-1}$, respectively, while the concentration of suspended solids was $3.9 \mathrm{mg} \mathrm{l}^{-1}$.

\subsubsection{Iodine species}

The most notable feature of the iodine distributions is that at all three samplings (Fig. 2), the iodate concentration in Lake Mir water was below the detection limit for the method. Meanwhile, between sampling occasions there is much variation in the shapes of the profiles for organic iodine while, in comparison, that for iodide is more uniform. Altogether, this imposes changes upon the shape of the profile for TI.

Over the top $5 \mathrm{~m}$, the iodide concentration depth-profile is essentially vertical, but with considerable variation between sampling occasions. For June and September 2010, and July 2011 the iodide concentrations are about $0.11,0.03$ and $0.06 \mu \mathrm{mol} \mathrm{l}^{-1}$, respectively. Tentatively then, there may be a seasonal pattern whereby iodide concentrations decrease from spring to summer. The small increase in iodide at the bottom in July 2011 may correspond with the similar trend in ammonium, except that an identical increase was evident in June 2010 without any corresponding change in the major constituents or ammonium. Accordingly, only a tentative deduction can be made here.

The vertical profiles of total iodine take on three different shapes over the period sampled, with the average concentration of $0.19 \mu \mathrm{mol} \mathrm{l}^{-1}$ in June 2010 and $0.12 \mu \mathrm{mol} \mathrm{l}^{-1}$ in September 2010 and July 2011. Meanwhile, the average organic-I concentrations were similar in June and September $2010\left(0.08 \mu \mathrm{mol} \mathrm{l}^{-1}\right)$ and ca. $30 \%$ lower in July $2011\left(0.05 \mu \mathrm{mol}^{-1}\right)$. Since the profiles for iodide were essentially vertical, except at depth in July 2011, the organicI profiles mostly follow those of total iodine. Accordingly, in June 2010 organic-I concentration was higher in the top $3 \mathrm{~m}$ of the water column, while in September 2010 concentrations were higher in deeper layers. The profile in July 2011 was rather uniform with depth (Fig. 2) and, because total organic carbon displays the same feature, the mean ratio ( \pm s.d.) between organic-I and TOC was within a narrow range of $(1.2 \pm 0.2) \cdot 10^{-4}$, the mole ratio which is consistent for in-situ formed organic matter. Within this setting, the shape of organic-I profile in September 2010 will be consistent with settling and accumulation of organic matter in deeper layers, which is also supported by diver observations of mucilaginous aggregates on the lake bottom. Additionally though, a strong south-east wind in September 2010 caused intensive foam production at the lake surface, and because the foam is found to be greatly enriched in organic-I (Truesdale et al., 2012), its production could have also affected organic-I distribution in the surface layers. In particular, the bubbles introduced by waves have the ability to effectively scavenge surfactant organic matter from the bulk water. Although wave action also mixes the surface layer, the net effect will be an increase in the amount of organic matter at the surface. Monahan (2001) describes this as, 'organic memory'.

\subsection{The 2011 time series investigation, twinned for open seawater and Lake Mir}

\subsubsection{The general variables}

Although there was very little salinity variation at the seawater station A1 (38.5 \pm 0.6$)$, at the Mir station L7 salinity was slightly lower (37.2) in early June, increasing steadily to 41.7 in October, at a steady rate $\left( \pm\right.$ s.e.) of $0.034( \pm 0.003) \mathrm{d}^{-1}$ (Fig. 3$)$; in accordance with the low amount of precipitation $(150 \mathrm{~mm})$, and hence net evaporation experienced between June and October (Station Velike Sestrice; Croatian Meteorological and Hydrological Service). The coefficient of determination $\left(r^{2}\right)$ for regression of salinity against time in seawater and in Mir were 0.406 (7 df) and 0.946 (10 df), respectively. The temperature for Lake Mir surface water was about $2{ }^{\circ} \mathrm{C}$ higher than that of the seawater. Similarly, a $t$-test $(p=0.05)$ showed that the alkalinity of Lake Mir water was significantly higher than that of seawater by an average of about $0.4 \mathrm{mmol} \mathrm{l}^{-1}$. Meanwhile, the $\mathrm{pH}$ of the open seawater was generally higher than in Lake Mir surface water; essentially it increased from 8.2 to 8.4 between June and October while the $\mathrm{pH}$ in lake water fluctuated more closely around a mean of 8.2, with the higher values between mid-July and October.

\subsubsection{The nutrient concentrations}

The total-P concentration of Lake Mir surface water was ca. 3 times greater than in the surface water of the open sea (Fig. 3). The phosphate concentration of the seawater was almost undetectable until the latter part of the year. Nevertheless, in Lake Mir concentrations of phosphate of about $0.1 \mu \mathrm{mol} 1^{-1}$ were present for much of the year, with a noticeable decrease in late July. The concentrations of ammonium, nitrite and nitrate were all very much higher and more dynamic in Lake Mir than in the open sea, generally 
Jun-10 $S, t \rho \mathrm{C}, \gamma(\mathrm{DO}) / \mathrm{mg} \mathrm{r}^{-1}$

$c$ (nutrients) $/ \mu \mathrm{moll}^{-1}$

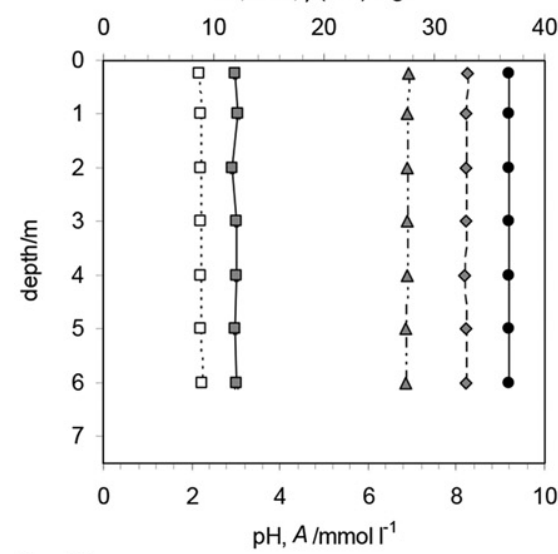

$\begin{array}{llllll}40 & 0.01 & 0.1 & 1 & 10 & 100\end{array}$
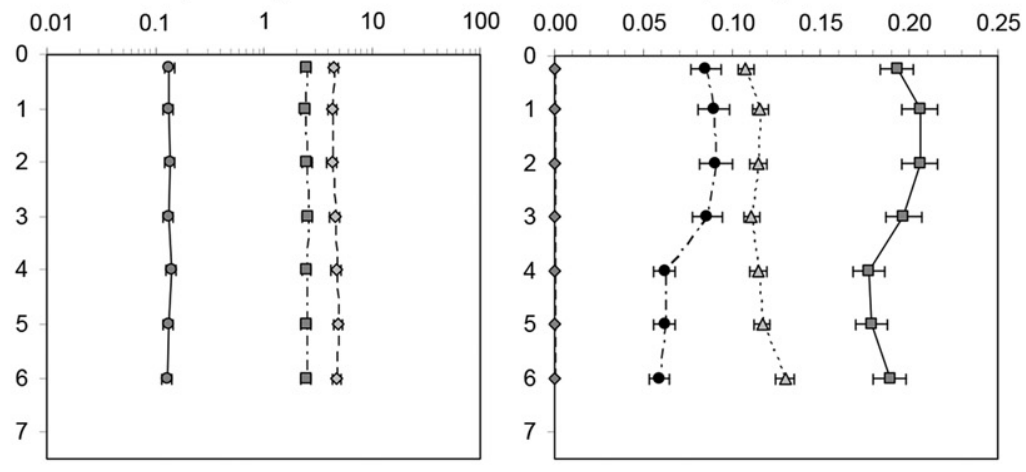

Sep-10
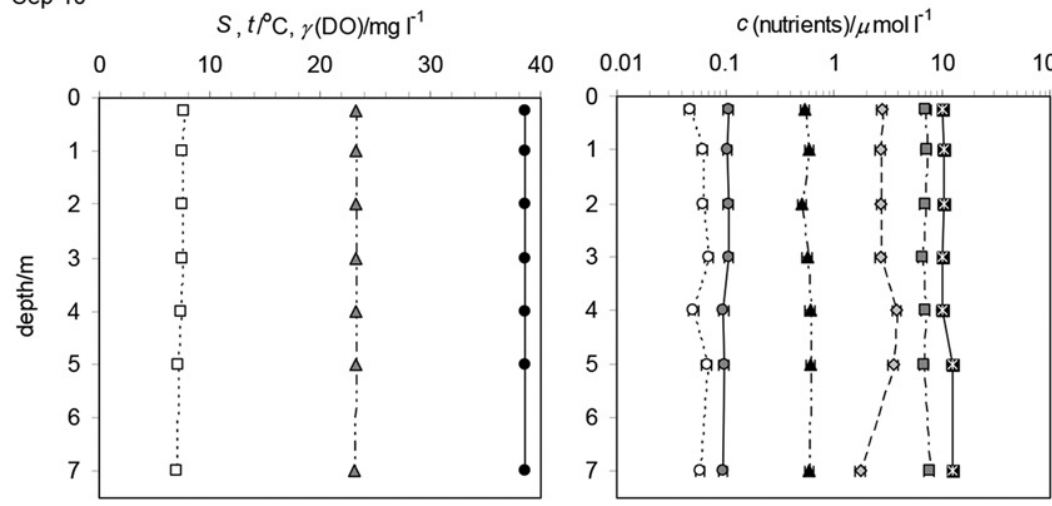

$c$ (iodine) $/ \mu \mathrm{moll}^{-1}$

$\begin{array}{lllllll}00 & 0.00 & 0.05 & 0.10 & 0.15 & 0.20 & 0.25\end{array}$

Jul-11
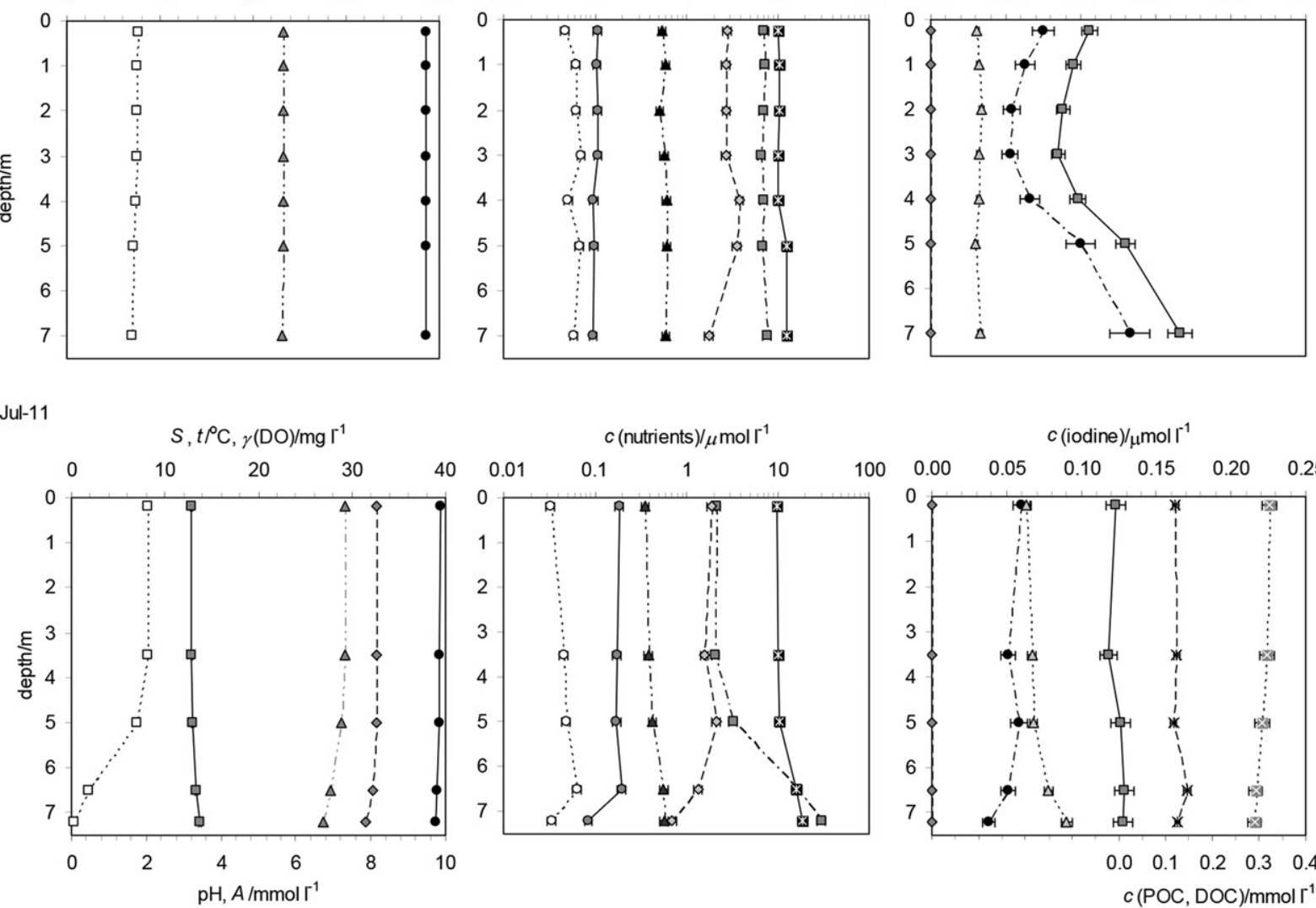

$100 \quad 0.00$

$c$ (iodine) $/ \mu \mathrm{mol} \mathrm{I}{ }^{-1}$
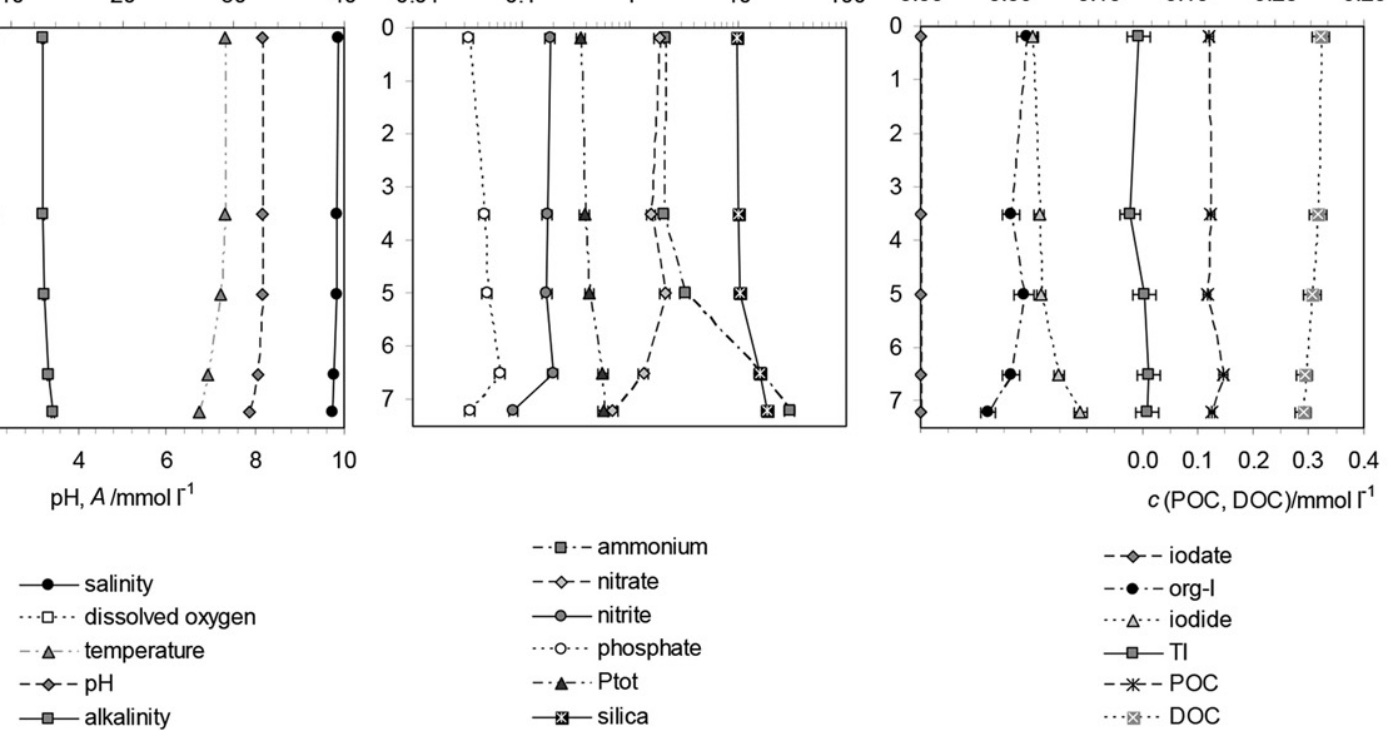

$$
\begin{aligned}
& -\diamond-\text { iodate } \\
& -\bullet-\text { org-I } \\
& \cdots \Delta \cdots \text { iodide } \\
& \rightarrow-\text { TI } \\
& -*-\text { POC } \\
& \cdots \times \text { DOC }
\end{aligned}
$$

Fig. 2. Profiles of main physico-chemical parameters (salinity, temperature, dissolved oxygen, $\mathrm{pH}$ and alkalinity), nutrients (ammonium, nitrate, nitrite, phosphate, total phosphorus and silica), and iodine species (iodate, iodide, organic-I and total iodine) at central lake station (C1) in June and September 2010 and July 2011 . On iodine graph for July 2011 particulate and dissolved organic carbon concentrations are also presented. Please note the log scale on nutrient profiles.

providing a U-shaped curve between June and October. The precise position of the minima for the curves does not appear to be identical. Up to August the concentration of silica in the lake surface water was about 2-10 times higher than in seawater, showing a notable maximum in July, while in the period that followed the concentrations and the patterns were more comparable (Fig. 3).
4.3.3. The variation of iodine species at the seawater sampling point The investigations of iodine in Adriatic seawater were primarily intended as a baseline or reference point for the Lake Mir study. However, as they are also of interest within the context of marine iodine chemistry they are firstly described in detail. The constancy of total iodine concentrations indicates that no appreciable gain or 

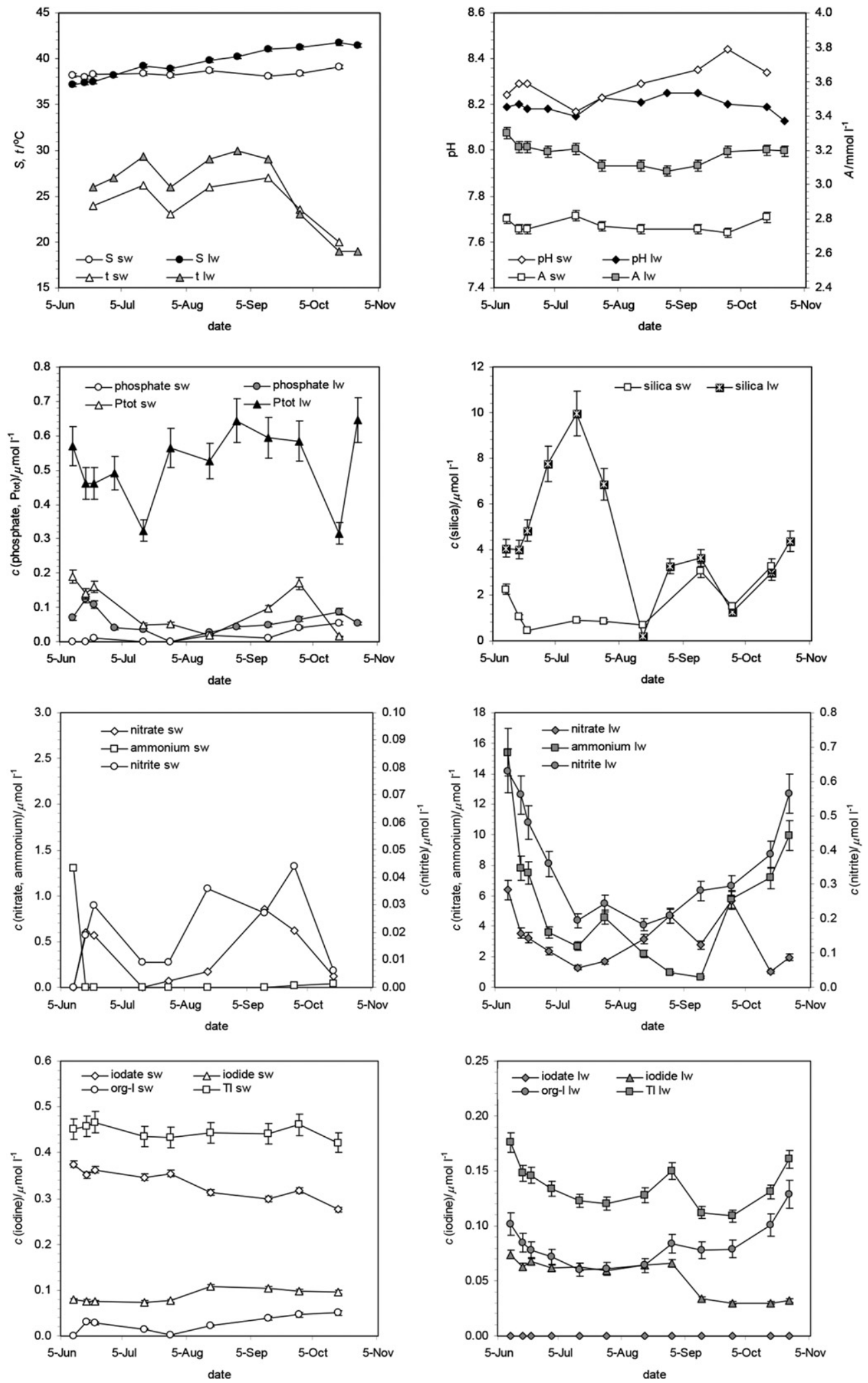

Fig. 3. The variation with time between June and November 2011 of the concentration of several species at sampling stations A1 (seawater, sw) and L7 (lake water, lw).

loss of iodine occurred over the investigated period. Meanwhile, iodate concentration decreased uniformly during the 130 days of investigation at a rate of $0.7( \pm 0.1) \mathrm{nmol} \mathrm{l}^{-1} \mathrm{~d}^{-1}$ (Fig. 4a). This was a robust result, as linear regression gave a coefficient of determination $\left(r^{2}\right)$ of 0.86 which is significant at $p=0.01$ using the Pearson correlation. In contrast, the iodide results are better taken as two trends: a more or less constant iodide concentration of $0.077 \mu \mathrm{mol}^{-1}$ over the first half of the period, followed by 

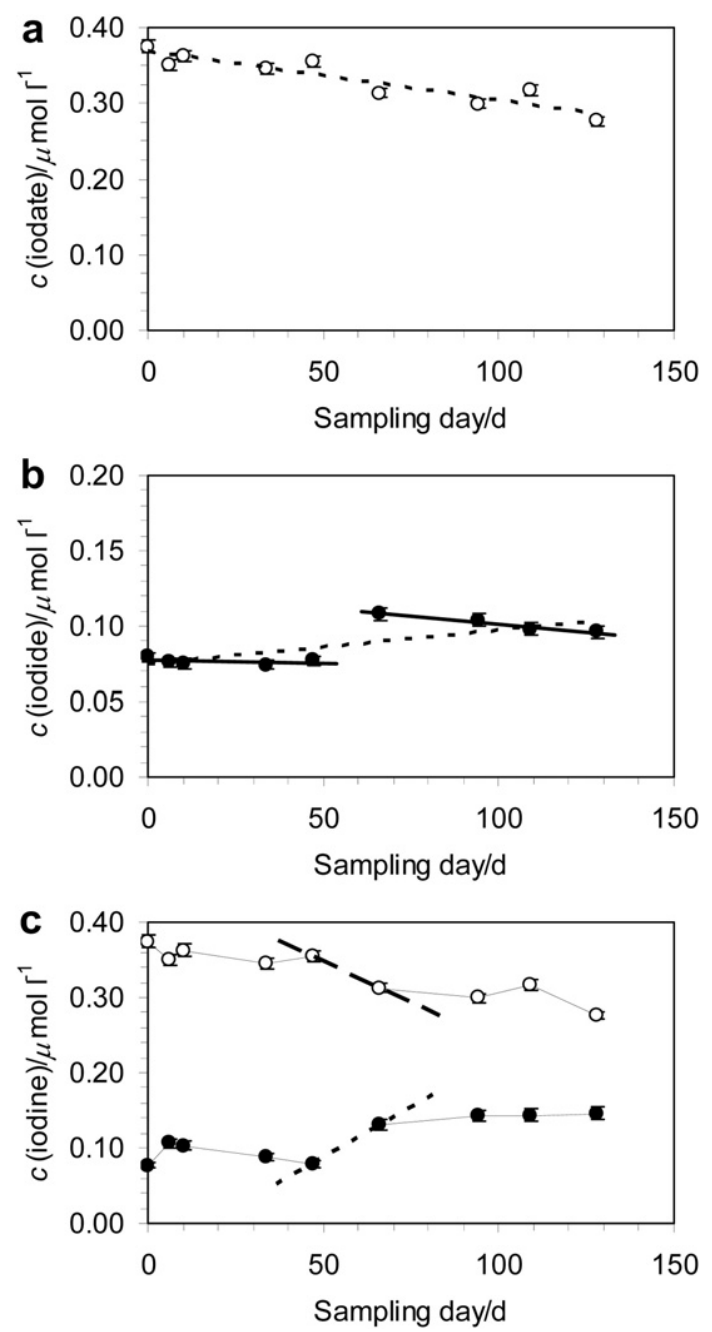

Fig. 4. Variation in the concentration of iodine species in Adriatic seawater. (a) Iodate; the dotted line is the linear regression line for the points. (b) Iodide; dotted line, as previously. Black lines are separate regressions for the 5 and 4 points, respectively. (c) Mirror-like images of iodate (white circles) and iodide + organic-I (black circles). The slopes (long-dashed for iodate and dotted for iodide + organic-I) are described within the text.

a steadily decreasing concentration rate of $0.2( \pm 0.03) \mathrm{nmol}^{-1} \mathrm{~d}^{-1}$ (Fig. 4b). The profile of organic-I (Fig. 3) suggests that after an initial decrease, it increased from about mid-summer until autumn. The organic-I results should be viewed with somewhat greater caution, since organic-I contributes only up to around $10 \%$ to TI. A subtraction of large numbers (organic- $\mathrm{I}=\mathrm{TI}$ - iodate - iodide) introduces higher uncertainty here.

An alternative view of the iodine system, which is also supported by iodine profiles on Fig. 3, is given by Fig. 4c, where the change in reduced iodine (iodide + organic-I) coincides with one in iodate. This de-couples the iodate concentration decrease over the sampling period into two distinct shorter periods, and since the reproducibility of the iodate measurements was $\pm 2 \%$, the change in the shape of the iodate profile is sufficiently reliable to support this view. Similarly, the profile of the combined reduced iodine species (iodide + organic-I) is also free of higher uncertainty, since reduced iodine is calculated as a difference between TI and iodate. A midperiod shift in the concentration of iodate, with a gradient of $-2.2 \mathrm{nmol} \mathrm{l}^{-1} \mathrm{~d}^{-1}$ is comparable to that of reduced iodine of $2.7 \mathrm{nmol} \mathrm{l}^{-1} \mathrm{~d}^{-1}$. The results tentatively suggest a seasonal pattern in iodine distribution, where iodate appears to be reduced at the expense of iodide and organic-I. However, given that the survey covered only the surface samples over the four-month period, it would be premature to give greater weight to this, even though it is potentially important an observation.

\subsubsection{Iodine species in Lake Mir}

The most notable result is the essential absence of iodate from the surface water of Lake Mir, as compared to that in open seawater where iodate concentration decreased steadily from $0.38 \mu \mathrm{mol} \mathrm{l}^{-1}$ in June to $0.28 \mu \mathrm{mol} \mathrm{l}^{-1}$ by the middle of October (Fig. 3). Meanwhile, the iodide concentration at both locations was very similar for about the first four months whence, in contrast to the slight increase in the open sea, in Lake Mir it decreased by about twice as much. Total iodine displayed a U-shaped curve in Lake Mir, similar to that of nitrogen species, while it remained essentially constant in the sea. These latter results for total iodine and iodide thereby imposed a U-shape upon the time-series graph for organic-I concentration in Lake Mir.

Although the lake is apparently well-isolated from the surrounding Adriatic, there appears to be a notable correlation between dissolved organic-I in the lake and in seawater. This was confirmed by a plot of the concentration of organic-I in the open seawater against that in Lake Mir water (Fig. 5a) which, provided the first point of the time-series was omitted, gave an $r^{2}$ of 0.721 and a statistically significant Pearson correlation coefficient at $p=0.01(d f=6)$. However, introducing the first point of the time series negates the correlation completely. The observed temporal similarity in organic-I, together with comparable organic-I/TOC mole ratios for the lake water and the Adriatic surface water in July $2011\left(1.2 \cdot 10^{-4}\right.$ and $1.5 \cdot 10^{-4}$, respectively) suggest that the (micro)biological processes, which are most likely involved, were similar at both locations.

Fig. 5 also suggested that for Lake Mir, total reduced iodine (iodide + organic-I) correlates well with each of the reduced nitrogen compounds (Fig. 5b), as all of these graphs are U-shaped. The separate regression of total iodine concentration upon those of ammonium and nitrite yielded $r^{2}$ of 0.51 and 0.56 , respectively, for the same 12 points and give statistically significant Pearson correlation coefficients at $p=0.01(d f=10)$, suggesting that the processes involved in nutrient dynamics also affect the iodine system. In contrast, the regression of TI against that of nitrate yielded $r^{2}=0.113$ and a statistically non-significant correlation.

\section{Discussion}

The marine lake, Mir, is an unusual natural environment in which various biogeochemical processes manifest themselves differently from those in the adjacent, open sea due to the specific geomorphology and hydrology of the lake isolating it from the sea. Concentration changes within the lake are not obscured by the rapid advection in of seawater. The isolation eliminates the inevitable problem of vertical advection between surface and deeper waters in open, marine systems. Overall, these conditions impose an overall reduced inventory (concentration) for iodine in the lake. The iodine system is additionally more simplified, since it is represented only by chemically reduced species, viz. iodide and organically bound iodine. These findings indicate that Lake Mir serves as a valuable outdoor laboratory for iodine studies.

\subsection{The isolation of Lake Mir}

If the $\approx 90 \mathrm{~m}$ of land separating Lake Mir from the Adriatic Sea were pervious to seawater the chemistry of Mir would have been identical to that of the sea. In fact, while an overall similarity in salinity, temperature, alkalinity and $\mathrm{pH}$ suggests a common origin 

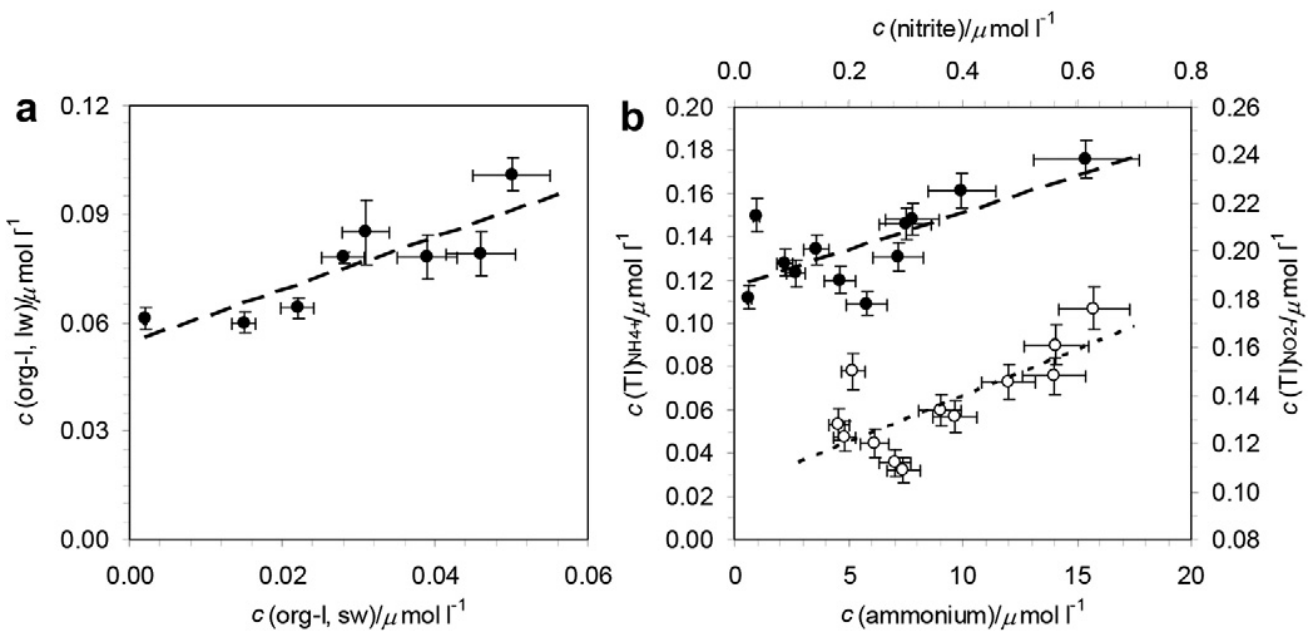

Fig. 5. The co-variation between various species in Lake Mir water and seawater. (a) Organic iodine in lake water versus organic iodine in seawater. (b) Total iodine versus ammonium (black circles), and nitrite (white circles) in the surface of the Lake Mir between June and November 2011. The best fit linear regression lines are shown.

for the two, the consistency of the differences between the two water bodies points to a sustained isolation of Mir water as shown by the saw-tooth shape of the salinity plot for seawater. This salinity change in the lake water from 42 to 37 would require about $600 \mathrm{~mm}$ of rain, assuming an average lake depth of $4 \mathrm{~m}$ and an area of $0.23 \mathrm{~km}^{2}$. This is comparable to the area's actual rainfall of 600-700 mm yr ${ }^{-1}$ (Džaja, 2003). However, as the rainfall and evaporation effectively occur in separate seasons, this imposes the saw-toothed shape upon the salinity versus time graph; this both supports and is supported by the longer data series of Carić et al. (2010). Even though these same processes also occur in seawater, a comparable rise in the salinity of the seawater will be dampened because the surface seawater will be mixed with deeper water, a feature not likely in Mir because of its isolation. This is supported by the more stable, $\approx 2{ }^{\circ} \mathrm{C}$ colder temperature of the Adriatic seawater; the smaller body of water is able to heat up more quickly. This is also reflected in the differences in the alkalinity and the $\mathrm{pH}$ between Mir and the sea although these are not necessarily as easy to explain as those for salinity and temperature. Alkalinity and $\mathrm{pH}$ are both involved in the carbonate system, which is affected by both photosynthesis and respiration and even, perhaps, calcite precipitation/dissolution within the Lake. The precise reasons for the differences are less relevant here but it is important that subtle differences occur, as these point to the isolation of Mir water.

In contrast to the subtle changes made against the large concentrations of the major variables of seawater, mentioned above, the low concentrations of the nutrients in Mir are markedly enriched relative to those in seawater. For example, the results show that at times ammonium- $\mathrm{N}$ and nitrate- $\mathrm{N}$ concentrations in Mir were 15 and 6 times greater, respectively, than those found in the seawater. Similarly, org-P seems to have been 3-6 times more concentrated. Even so, these differences still support the isolation thesis for Mir. Moreover, since the runoff is low (Džaja, 2003), as shown here from the subtle annual salinity variations, the atmospheric (wet plus dry) deposition is considered to be the most important source of nutrients to the Lake. Between 2006 and 2010, the average annual nitrate and ammonium supply via atmospheric deposition at Zadar, the station closest to the Lake Mir, was 0.8 $( \pm 0.3) \mathrm{g} \mathrm{m}^{-2}$ (Statistical Yearbooks of the Republic of Croatia, http://www.dzs.hr/hrv/publication/stat_year.htm). Such a flux would be sufficiently high to increase the inorganic nitrogen concentration in the entire water column by about $14( \pm 6) \mu \mathrm{mol}^{-1}$ $\mathrm{yr}^{-1}$, in approximately equal proportions of nitrate and ammonium.
This, for example, accords with the global atmospheric loading rates of total $\mathrm{N}$ of up to $3 \mathrm{~g} \mathrm{~m}^{-2} \mathrm{yr}^{-1}$ (Shaw et al., 1989). Given the almost persistent phosphorus limitation in Lake Mir water (Carić et al., 2010 and Fig. 3 in this study), it appears that the atmospheric phosphorus deposition in this area is well below that required for a Redfield N:P ratio of 16:1, as observed in some other lake environments (Jassby et al., 1994). Overall then, the annual nutrient condition in Mir water reflects the balance between the atmospheric nutrient input, a highly restricted water exchange with the surrounding Adriatic, and the biological cycling within the lake.

\subsection{The reduced total-iodine inventory in the lake}

At about $0.14 \mu \mathrm{mol} \mathrm{l}^{-1}$, the total iodine concentration in Mir is only about one-third of the equivalent concentration of that in seawater. Thus, the iodine results provide one-third, independent strand of evidence to support the isolation thesis for Mir. In this case, however, instead of representing a process of enrichment, they represent a loss although the processes responsible for the nutrient enrichment may still be responsible for the iodine depletion. Thus, unlike the $\mathrm{N}$-nutrients, atmospheric iodine deposition is typically less than $0.01 \mu \mathrm{mol} \mathrm{l}^{-1}$ (Truesdale and Jones, 1996; Baker et al., 2001; Gilfedder et al., 2008a,b). Accordingly, when a simple calculation is made for the Mir area based upon dry- and wetdeposition iodine fluxes of up to $9.2 \mu \mathrm{mol} \mathrm{m} \mathrm{mr}^{-1}$ for a coastal site (Baker et al., 2001), the annual flux from the atmosphere is only sufficiently high to increase the inorganic iodine concentration in the water column by $\approx 0.002 \mu \mathrm{mol} \mathrm{l}^{-1}$. Even if allowance is made for an organically bound iodine, which is ubiquitous in both rainwater and aerosol (see: Saiz-Lopez et al., 2012 for a detailed review), the flux still appears to be too low to affect the water column. Indeed, the accompanying study of foams formed on the surface of Lake Mir (Truesdale et al., 2012) suggests that the lake acts rather as a source of atmospheric iodine. In particular, natural foams from Lake Mir are enrichened in organic-I up to 630 times relative to the surface water in the lake, and it is argued that organic-I is enriched in the lake micro-layer, becoming available as a supply-flux of iodine to the marine aerosol.

The iodine profiles (Figs. 2 and 3 ) are consistent with the iodine system being markedly affected by biological cycling (starting with phytoplankton, and ending in regeneration). This is supported by the organic-I/TOC mole ratio of $(1.2 \pm 0.2) \cdot 10^{-4}$ in the lake water 
(Sec. 4.2.4), which is close to the literature value of $(1.0-1.6) \cdot 10^{-4}$ for $\mathrm{I} / \mathrm{C}$ assimilation ratios in seston in the Pacific Ocean (Elderfield and Truesdale, 1980) and coastal Antarctic Ocean (Chance et al., 2010). The ratio is also comparable to $\mathrm{TI}_{\text {diss. }} / \mathrm{DOC}$ ratio of 2.7 $( \pm 0.5) \cdot 10^{-4}$ for the water column of a humic-rich freshwater lake (Mummelsee) (Gilfedder et al., 2009), where sediment-core iodine supports efficient biological uptake. Therefore, although the water column of Lake Mir seems to be well mixed during most of the year, it can be reasonably presumed that at least some of the iodine would be ultimately deposited into the sediment, since the contribution of POC to TOC is high (Sec. 4.2.3), and the surface sediments of Lake Mir seem to be in contact with well-oxygenated water during most of the year. Thus, Price and Calvert (1973) demonstrated that, relative to anoxic sediments, oxic ones are enriched in iodine. Therefore, the iodide flux from the lake sediment would only be pronounced during short periods of eventual anoxia in the near bottom layer (Gilfedder et al., 2009; Chapman and Truesdale, 2011).

The lack of anoxic conditions within the water column of the Lake Mir, together with a more restricted water exchange and lower terrestrial influence, also explains the large difference in the iodine budget between the Lake Mir and the nearby anchialine pond, Rogoznica Lake (Croatian: Zmajevo oko - Dragon's Eye). There, anoxic and sulfidic conditions in the sediment and bottom water promote iodine remobilisation during early diagenesis, and iodide diffuses from the lake sediment (Žic and Branica, 2006). Additionally, given that the amount of suspended solids in Lake Mir is also high, another pathway of iodine burial into the sediment may involve sorption of inorganic constituents onto solid-phases (e.g., Neal and Truesdale, 1976; Ullman and Aller, 1985). Against this background, although restricted, the water exchange between the Lake Mir and the surrounding Adriatic probably prevents this aquatic environment from becoming eutrophic, yet helps maintain the depletion in iodine. Therefore, over a prolonged period a quasisteady state could be attained, with the overall reduced-iodine inventory in the lake.

\subsection{A context for Mir iodine chemistry based upon the distributions of the nutrients}

Our nutrient results show that Lake Mir is meso-trophic, rather than oligotrophic, as is the surrounding Adriatic Sea. Thus, the maximum ammonium, nitrate, phosphate and silicate concentrations in Mir are about $16,6,0.15$, and $10 \mu \mathrm{mol} \mathrm{l}^{-1}$, respectively, and these are often more typical of nutrient concentrations normally found in the temperate-zone coastal waters in winter, prior to the spring algal bloom (e.g., Ewins and Spencer, 1967). The influence of biology upon the distribution of nutrients in Lake Mir has been described by Čalić et al. (2007) and Carić et al. (2010), who give much information about the particular species of phytoplankton. From this it seems that nutrient cycling in Lake Mir follows a conventional pattern involving a net reaction between uptake and regeneration by micro-organisms.

It is concluded that Lake Mir presents a marine environment similar to a temperate zone coastal water, but without the complication of winter advection from deeper water. In this respect it ought to display the nutrient cycling properties associated with temperate waters to an enhanced degree. By the same argument, advection of iodate-rich deeper water into temperate surface waters has the capacity to mask iodate reduction. This argument would seem to explain the apparent absence of iodate in Lake Mir. The term, 'absence' is an operational expression, defined by our inability to determine iodate concentrations lower than $\approx 0.015 \mu \mathrm{mol} \mathrm{l}^{-1}$. Therefore, against the overall reduced iodine inventory in the lake water, a small amount may represent as much as $10-15 \%$ of the iodine inventory, which is not insubstantial. It is, nevertheless, quite clear that the system promotes iodate reduction and/or uptake. The literature about this topic provides numerous possible explanations such as bacterial action during decomposition (Truesdale, 1994a; Truesdale and Bailey, 2002); dissimilatory iodate reduction by bacteria (Amachi et al., 2007); phytoplankton uptake and iodate reduction (Moisan et al., 1994; Wong et al., 2002; Chance et al., 2007); abiotic factors when the iodine system is exposed to reducing conditions (Zhang and Whitfield, 1986; Bluhm et al., 2010). None of these possible pathways is preferred at the moment, since all might well affect iodine speciation simultaneously.

The lack of iodate in Mir water could also support the hypothesis that iodide oxidation to iodate possibly runs in parallel with nitrification (Truesdale et al., 2001b), as supported by observations in several anchialine water bodies along the Croatian coastline (Žic et al., 2008, 2010, 2011). The inorganic nitrogen speciation over this study supports this as nitrate-nitrogen seems to be largely chemically depressed relative to ammonium and to organic-N. This is deduced from the foam study where natural foams and laboratory-foams generated from the Lake Mir surface water were also enrichened in organic-N (Truesdale et al., 2012). A possible exception might be in the late winter period (Carić et al., 2010), when low iodate concentrations were detected in the lake. However, closer inspection of the nitrate and ammonium profiles and that of salinity presented by Caric et al. (2010) suggests that it is far more likely that the late-winter increase in concentration of both species can be ascribed to atmospheric input and not in-situ nitrification. Within this context, the system differs markedly from several aquatic environments where iodate formation can be linked to regenerated nitrate (Žic et al., 2008, 2010; Gilfedder et al., 2009). The lack of stratification in the Lake Mir and the fragility of a consortium of the ammonium and nitrite oxidising bacteria and/or archaea (Ward, 2008) may inhibit nitrification. Therefore, the data provide direct evidence that the iodine system in Lake Mir is relatively similar to the nutrient pattern of up-take and regeneration of the nutrients, with its prevalence toward reduced species.

In addition, in this system rich in organic matter, photochemical processes might ultimately contribute to an inter-conversion between the reduced iodine species within the water column (Truesdale et al., 1995; Spokes and Liss, 1996; Wong and Cheng, 2001b).

\section{Conclusions}

Lake Mir provides a meso-trophic marine environment separated from the coastal, Adriatic Sea by about $90 \mathrm{~m}$ of karstified carbonate rock. The additional nutrients available to Mir seem likely to arise from both wet and dry atmospheric precipitation. The more intensive nutrient cycling in Mir compared to the open seawater is accompanied by a more intensive iodine chemistry such that iodate is essentially absent, and iodide much reduced in concentration. Conversely, however, an organic-I component is more prevalent than in the open sea, amounting up to $80 \%$ of the total iodine. The reduced iodine inventory in the lake supports the isolation thesis for Mir.

Although the measurements made at the open sea station were intended as a reference set for Lake Mir, they showed a steady decrease in iodate concentration over the 130 days of study between June and October. It is too early to ascribe these changes to in situ iodate reduction because it is possible that water has flowed past the sampling point. As always with iodine, advective effects can give a false impression of a seasonal chemical reduction. Despite this, the effect warrants further investigation especially as so few temporal effects of iodine have been studied. 


\section{Acknowledgement}

We would like to thank the expert associate, Ms. Milena Ramov and other personnel from Nature Park Telašćica for generous help in sampling. The financial support of the Ministry of Science, Education and Sports of the Republic of Croatia, under Project 098-0982934-2720, "'Interactions of trace metals in aquatic environment"', is gratefully acknowledged. We thank the Croatian Meteorological and Hydrological Service for meteorological data. We also thank two anonymous reviewers for their valuable comments.

\section{References}

Amachi, S., Kawaguchi, N., Muramatsu, Y, Tsuchiya, S., Watanabe, Y., Shinoyama, H. Fujii, T., 2007. Dissimilatory iodate reduction by marine Pseudomonas sp. strain SCT. Applied and Environmental Microbiology 73, 5725-5730.

Baker, A.R., Tunnicliffe, C., Jickells, T.D., 2001. Iodine speciation and deposition fluxes from the marine atmosphere. Journal of Geophysical Research 196 28743-28749.

Benner, R., Strom, M., 1993. A critical evaluation of the analytical blank associated with DOC measurements by high-temperature catalytic oxidation. Marine Chemistry 41, 153-160.

Bluhm, K., Croot, P., Wuttig, K., Lochte, K., 2010. Transformation of iodate to iodide in marine phytoplankton driven by cell senescence. Aquatic Biology 11, 1-15.

Bower, C.E., Holm-Hansen, T., 1980. A salicylate-hypochlorite method for determining ammonia in seawater. Canadian Journal of Fisheries and Aquatic Sciences 37, 794-798.

Broecker, W.S., Peng, T.-h., Beng, Z., 1982. Tracers in the Sea. Eldigio Press.

Butler, E.C.V., Smith, J.D., 1980. Iodine speciation in seawater - the analytical use of ultra-violet photo-oxidation and differential pulse polarography. Deep-Sea Research 27, 489-493.

Calić, M., Carić, M., Jasprica, N., 2007. Hydrography and Planktonic Diatoms in the Marine Lake Mir (Eastern Adriatic Sra, Croatia). In: Rapp. Comm. int. Mer Médit., vol. 38, Monaco, p. 354

Campos, M.L.A.M., Farrenkopf, A.M., Jickells, T.D., 1996. A comparison of dissolved iodine cycling at the Bermuda Atlantic time-series station and Hawaii ocean time-series station. Deep-Sea Research II 43, 455-466.

Campos, M.L.A.M., Sanders, R., Jickells, T.D., 1999. The dissolved iodide and iodate distribution in the South Atlantic from the Weddell Sea to Brazil. Marine Chemistry 65, 167-175.

Carić, M., Čalić, M., Jasprica, N., 2010. Annual Distribution of Nutrients and Phytoplankton in the Marine Lake Mir (Middle Adriatic). In: Rapp. Comm. Int. Mer Medit., vol. 39, Venice, Italy, p. 340

Chance, R., Malin, G., Jickells, T.D., Baker, A.R., 2007. Reduction of iodate to iodide by cold water diatom cultures. Marine Chemistry 105, 169-180.

Chance, R., Weston, K., Baker, A.R., Hughes, C., Malin, G., Carpenter, L. Meredith, M.P., Clarke, A., Jickells, T.D., Mann, P., Rossetti, H., 2010. Seasonal and interannual variation of dissolved iodine speciation at a coastal Antarctic site. Marine Chemistry 118, 171-181.

Chapman, P., Truesdale, V.W., 2011. Preliminary evidence for iodate reduction in bottom waters of the Gulf of Mexico during an hypoxic event. Aquatic Geochemistry 17, 671-695.

Cook, P.L.M., Carpenter, P.D., Butler, E.C.V., 2000. Speciation of dissolved iodine in the waters of a humic-rich estuary. Marine Chemistry 69, 179-192.

Currie, L.A., Svehla, Gy, 1994. Nomenclature for the presentation of results of chemical analysis. Pure and Applied Chemistry 66, 595-608.

Džaja, K., 2003. Geomorfološke značajke Dugog otoka. Geoadria 8, 5-44 (in Croatian).

Elderfield, H., Truesdale, V.W., 1980. On the biophilic nature of iodine in seawater Earth and Planetary Science Letters 50, 105-114.

Ewins, P.A., Spencer, C.P., 1967. The annual cycle of nutrients in the Menai Straits. Journal of Marine Biology Association UK 47, 533-542.

Gilfedder, B.S., Lai, S.C., Petri, M., Biester, H., Hoffmann, T., 2008a. Iodine speciation in rain and snow. Atmospheric Chemistry and Physics 8, 6069-6084.

Gilfedder, B.S., Lai, S., Petri, M., Biester, H., Hoffmann, T., 2008b. Iodine speciation in rain, snow and aerosols and possible transfer of organically bound iodine species from aerosol to droplet phases. Atmospheric Chemistry and Physics Discussions 8, 7977-8008

Gilfedder, B.S., Petri, M., Biester, H., 2009. Iodine speciation and cycling in fresh waters: a case study from a humic rich headwater lake (Mummelsee). Journal of Limnology 68, 296-408.

Gilfedder, B.S., Petri, M., Wessels, M., Biester, H., 2010. An iodine mass-balance for Lake Constance, Germany: insights into iodine speciation changes and fluxes. Geochimica et Cosmochimica Acta 74, 3090-3111.

Herring, J.R., Liss, P.S., 1974. A new method for the determination of iodine species in seawater. Deep-Sea Research 21, 777-783.

Holthuis, L.B., 1973. Caridean shrimps found in land-locked saltwater pools at four Indo-West Pacific localities (Sinai Peninsula, Funafuti atoll, Maui and Hawail
Islands), with the description of one new genus and four new species. Zoologische Verhandelingen 128, 1-48.

Humphreys, W.F., 2009. Hydrogeology and groundwater ecology: does each inform the other? Hydrogeology Journal 17, 5-21.

Jassby, A.D., Reuter, J.E., Axler, R.P., Goldman, C.R., Hackley, S.H., 1994. Atmospheri deposition of nitrogen and phosphorus in the annual nutrient load of Lake Tahoe (California-Nevada). Water Resources Research 30, 2207-2216.

Lorrain, A., Savoye, N., Chauvaud, L, Paulet, Y.-M., Naulet, N., 2003. Decarbonation and preservation method for the analysis of organic $\mathrm{C}$ and $\mathrm{N}$ contents and stable isotope ratios of low-carbonated suspended particulate material. Analytica Chimica Acta 491, 125-133.

Louis, Y., Garnier, C., Lenoble, V., Mounier, S., Cukrov, N., Omanović, D., Pižeta, I. 2009. Kinetic and equilibrium studies of copper-dissolved organic matte complexation in water column of the stratified Krka River estuary (Croatia). Marine Chemistry 114, 110-119.

Luther III, G.W., Swartz, C.B., Ullman, W.J., 1988. Direct determination of iodide in seawater by cathodic stripping square wave voltammetry. Analytical Chemistry $60,1721-1724$.

Luther III, G.W., Ferdelman, T., Culberson, C.H., Kostka, J., Wu, J., 1991. Iodine chemistry in the water column of the Chesapeake Bay: evidence for organic iodine forms. Estuarine, Coastal and Shelf Science 32, 267-279.

McTaggart, A.R., Butler, E.C.V., Haddad, P.R., Middleton, J.H., 1994. Iodide and iodate concentrations in eastern Australian subtropical waters, with iodide by ionchromatography. Marine Chemistry 30, 159-172.

Millero, F.J., 2006. Chemical Oceanography, third ed. CRC Press, New York.

Moisan, T.A., Dunstan, W.M., Udomkit, A., Wong, G.T.F., 1994. The uptake of iodate by marine phytoplankton. Journal of Phycology 30, 580-587.

Monahan, E.C., 2001. Whitecaps and foam. In: Steele, J., Thorpe, S., Turekian, K. (Eds.), Encyclopedia of Ocean Sciences. Academic Press, London.

Moore, W.S., 1999. The subterranean estuary: a reaction zone of ground water and sea water. Marine Chemistry 65, 111-125.

Nakayama, E., Kimoto, T., Isskiki, K., Sohrin, Y., Okazaki, S., 1989. Determination and distribution of iodide and total-iodine in the North Pacific Ocean-by using a new automated electro-chemical method. Marine Chemistry 27, 105-116.

Neal, C., Truesdale, V.W., 1976. The sorption of iodate and iodide by riverine sediments: its implications to dilution gauging and hydrochemistry of iodine. Journal of Hydrology 31, 281-291.

Omanović, D., Branica, M., 1998. Automation of voltammetric measurements by polarographic analyser PAR 384B. Croatica Chemica Acta 71, 421-433.

Omanović, D., 2006. ECDSOFT - ElectroChemistry Data SOFTware. http://www.irb. $\mathrm{hr} / \mathrm{en} / \mathrm{str} / z i m o /$ laboratoriji/lfkt/djelatnici/DarioOmanovic/Software/.

Pižeta, I., Omanović, D., Branica, M., 1999. The influence of data treatment on the interpretation of experimental results in voltammetry. Analytica Chimica Acta 401, 163-172.

Price, N.B., Calvert, S.E., 1973. The geochemistry of iodine in oxidised and reduced recent marine sediments. Geochimica et Cosmochimica Acta 37, 2149-2158.

Saiz-Lopez, A., Plane, J.M.C., Baker, A.R., Carpenter, L.J., von Glasow, R., Gómez Martín, J.C., McFiggans, G., Saunders, R.W., 2012. Atmospheric chemistry of iodine. Chemical Reviews 112, 1773-1804.

Schwehr, K.A., Santschi, P.H., 2003. Sensitive determination of iodine species, including organo-iodine, for freshwater and seawater samples using high performance liquid chromatography and spectrophotometric detection. Analytica Chimica Acta 182, 59-71.

Schwehr, K.A., Santschi, P.H., Elmore, D., 2005. The dissolved organic iodine species of the isotopic ratio of 129I/127I: a novel tool for tracing terrestrial organic carbon in the estuarine surface waters of Galveston Bay, Texas. Limnology and Oceanography: Methods 3, 326-337.

Shaw, R.D., Trimbee, A.M., Minty, A., Fricker, H., Prepas, E.E., 1989. Atmospheric deposition of phosphorus and nitrogen in Central Alberta with emphasis on Narrow Lake. Water, Air and Soil Pollution 43,119-134.

Shaw, T.I., 1959. The mechanism of iodide accumulation by the brown sea weed L. digitata. The uptake of 131I. Proceedings of the Royal Society, B 150 356-371.

Spokes, L.J., Liss, P.S., 1996. Photochemically induced redox reactions in seawater: II. Nitrogen and iodine. Marine Chemistry 54, 1-10.

Stipaničev, V., Branica, M., 1996. Iodine speciation in the water column of the Rogoznica Lake (Eastern Adriatic Coast). Science of the Total Environment 182 $1-9$.

Strickland, J.D.H., Parsons, T.R., 1968. A Practical Handbook of Sea Water Analyses. In: Fisheries Research Board of Canada, Bulletin, vol. 167. Ottawa.

Sugawara, K., Terada, K., 1957. Iodine distribution in the western Pacific Ocean. The Journal of Earth Sciences (Nagoya University) 5, 81-102.

Sugawara, K. Terada, K 1967. Iodine assimilation by the marine Navicula sp. and the production of iodate accompanied by the growth of the algae. Information Bulletin on Planktology in Japan (Commemoration Number of Dr Y. Matsue) 14 213-218.

Truesdale, V.W., Bailey, G.W., 2000. Dissolved iodate and total iodine during an extreme hypoxic event in the southern Benguela system. Estuarine, Coastal and Shelf Science 50, 751-760.

Truesdale, V.W., Bailey, G.W., 2002. Iodine distribution in the Southern Benguela system during an up-welling episode. Continental Shelf Research 22, 39-49.

Truesdale, V.W., Jones, S.D., 1996. The variation of iodate and total iodine in some UK rainwaters during 1980-1981. Journal of Hydrology 179, 67-86.

Truesdale, V.W., Jones, K., 2000. Steady-state mixing of iodine in Shelf Seas off the British Isles. Continental Shelf Research 20, 1889-1905. 
Truesdale, V.W., Upstill-Goddard, R., 2003. Dissolved iodate and total iodine along the British east coast. Estuarine, Coastal and Shelf Science 56, 261-270.

Truesdale, V.W., Canosa-Mas, C.E., Luther III, G.W., 1995. Disproportionation and reduction of molecular iodine added to seawater. Marine Chemistry 51, 55-60.

Truesdale, V.W., Bale, A.J., Woodward, M., 2000. The meridional distribution of dissolved iodine in near surface waters of the Atlantic Ocean. Progress in Oceanography $45,387-400$.

Truesdale, V.W., Nausch, G., Baker, A., 2001a. The distribution of iodine in the Baltic Sea during summer. Marine Chemistry 74, 87-98.

Truesdale, V.W., Watts, S.F., Rendell, A.R., 2001b. On the possibility of iodide oxidation in the near-surface of the Black Sea and its implications to iodine in the general ocean. Deep-Sea Research I 48, 2397-2412.

Truesdale, V.W., Danielssen, D.S., Waite, T.J., 2003a. Summer and winter distributions of dissolved iodine in the Skagerrak. Estuarine, Coastal and Shelf Science 57, 701-713.

Truesdale, V.W., Kennedy, H., Agustí, S., Waite, T.J., 2003b. On the relative constancy of iodate and total-iodine concentrations accompanying phytoplankton blooms initiated in mesocosm experiments in Antarctica. Limnology and Oceanography 48, 1569-1574

Truesdale, V.W., Žic, V., Garnier, C., Cukrov, N., 2012. Circumstantial evidence in support of org-I as a component of the marine aerosol arising from a study of marine foams. Estuarine, Coastal and Shelf Science 115, 388-398.

Truesdale, V.W., 1975. 'Reactive' and 'unreactive' iodine in seawater - a possible indication of an organically bound iodine fraction. Marine Chemistry 3, 111-119.

Truesdale, V.W., 1978. Iodine in inshore and offshore waters. Marine Chemistry 6, $1-13$.

Truesdale, V.W., 1994a. A re-assessment of Redfield correlations between dissolved iodine and nutrients in oceanic waters, and a strategy for further investigations of iodine. Marine Chemistry 48, 43-56.

Truesdale, V.W., 1994b. Distribution of dissolved iodine in the Irish Sea, a temperate Shelf Sea. Estuarine, Coastal and Shelf Science 38, 435-446.

Tsunogai, S., Henmi, T., 1971. Iodine in the surface water of the ocean. Journal of the Oceanographical Society of Japan 27, 67-72.

Tsunogai, S., Sase, T., 1969. Formation of iodide iodine in the ocean. Deep-Sea Research I 16, 489-496.

Ullman, W.J., Aller, R.C., 1985. The geochemistry of iodine in nearshore carbonate sediments. Geochimica et Cosmochimica Acta 49, 967-978.

Waite, T.J., Truesdale, V.W., 2003. Iodate reduction by Isochrysis galbana is relatively insensitive to de-activation of nitrate reductase activity are phytoplankton really responsible for iodate reduction in seawater? Marine Chemistry 81, $137-148$.

Waite, T.J., Truesdale, V.W., Olafsson, J., 2006. The distribution of dissolved inorganic iodine in the seas around Iceland. Marine Chemistry 101, 54-67.

Ward, B.B., 2008. Nitrification. In: Capone, D.G., Bronk, D.A., Mulholland, M.R., Carpenter, E.J. (Eds.), Nitrogen in the Marine Environment. Elsevier, Amsterdam, pp. 199-262.
Wong, G.T.F., Brewer, P.G., 1977. The marine chemistry of iodine in anoxic basins. Geochimica et Cosmochimica Acta 41, 151-159.

Wong, G.T.F., Cheng, X.-H., 1998. Dissolved organic iodine in marine waters: determination, occurrence and analytical implications. Marine Chemistry 59, 271-281.

Wong, G.T.F., Cheng, X.-H., 2001a. Dissolved iodine in marine waters: role in the estuarine geochemistry of iodine. Journal of Environmental Monitoring 3, 257-263.

Wong, G.T.F., Cheng, X.H., 2001b. The formation of iodide in inshore waters from the photochemical decomposition of dissolved organic iodine. Marine Chemistry $74,53-64$.

Wong, G.T.F., Zhang, L.-S., 1992a. Changes in the iodine speciation across hydrographic fronts in southeastern United States continental shelf waters. Continental Shelf Research 12, 717-733.

Wong, G.T.F., Zhang, L.-S., 1992b. Chemical removal of oxygen with sulfite for the polarographic or voltammetric determination of iodate of iodide in seawater. Marine Chemistry 38, 109-116.

Wong, G.T.F., Zhang, L.-S., 2003. Seasonal variations in the speciation of dissolved iodine in the Chesapeake Bay. Estuarine, Coastal and Shelf Science 56, 1093-1106.

Wong, G.T.F., Takayanagi, K., Todd, J.F., 1985. Dissolved iodine in waters overlying the Orca basin, Gulf of Mexico. Marine Chemistry 17, 177-183.

Wong, G.T.F., Piumsomboon, A.U., Dunstan, W.M., 2002. The transformation of iodate to iodide in marine phytoplankton cultures. Marine Ecology Progress Series 237, 27-39.

Wong, G.T.F., 1991. The marine geochemistry of iodine. Reviews in Aquatic Sciences $4,45-73$.

Wong, G.T.F., 1995. Dissolved iodine across the Gulf Stream Front and in the South Atlantic Bight. Deep-Sea Research I 42, 2005-2023.

Zhang, J.-Z., Fischer, C.J., 2006. A simplified resorcinol method for direct spectrophotometric determination of nitrate in seawater. Marine Chemistry 99, 220-226.

Zhang, J.-Z., Whitfield, M., 1986. Kinetics of inorganic redox reactions in seawater. I. The reduction of iodate by bisulphide. Marine Chemistry 19, 121-137.

Žic, V., Branica, M., 2006. The distributions of iodate and iodide in Rogoznica Lake (East Adriatic Coast). Estuarine, Coastal and Shelf Science 66, 55-66.

Žic, V., Truesdale, V.W., Cukrov, N., 2008. The distribution of iodide and iodate in anchialine cave waters - evidence for sustained localised oxidation of iodide to iodate in marine water. Marine Chemistry 112, 168-178.

Žic, V., Carić, M., Viollier, E., Ciglenečki, I., 2010. Intensive sampling of iodine and nutrient speciation in naturally eutrophicated anchialine pond (Rogoznica Lake) during spring and summer seasons. Estuarine, Coastal and Shelf Science 87, 265-274.

Žic, V., Truesdale, V.W., Cuculić, V., Cukrov, N., 2011. Nutrient speciation and hydrography in two anchialine caves in Croatia: tools to understand iodine speciation. Hydrobiologia 677, 129-148. 